\title{
JournEEL
}

ISSN 2721-611X Vol. 3. No. 2, December 2021, Page. 60-70

\section{Quizizz as Distance Learning Tool: Effects and Students' Opinion}

\author{
Lulu Salma Fajria \\ UIN Syarif Hidayatullah Jakarta, email: lulu.salmafajria19@mhs.uinjkt.ac.id \\ Sarah Fitria \\ UIN Syarif Hidayatullah Jakarta, email: sarah.fitria19@mhs.uinjkt.ac.id \\ Tanalina Hasnata Saniata Azta Ramadani \\ UIN Syarif Hidayatullah Jakarta, email: tanalina.hasnata19@mhs.uinjkt.ac.id
}

\begin{abstract}
The purposes of this study are: (1) To determine the effect of using Quizizz as a distance learning tool, and (2) To determine students' opinions of Quizizz as a distance learning tool. The participants of this study consisted of an English teacher and thirty-one eleventh-grade students. The data used in this study are in the form of interview results, description of students' final grades, and the result of questionnaire. The method used is a mixed-method - qualitative and quantitative, with three instruments: Likert Scale questionnaire, interview, and students' final score. The main findings of this study are: (1) Positive effects in increasing students' learning motivation, competitiveness, and academic achievement in grammar and reading when using Quizizz as a distance learning tool, and (2) Students' positive opinions towards Quizizz's interesting appearance, challenging features, and their enjoy feelings while using Quizizz as distance learning tool.
\end{abstract}

Keywords: Quizizz, distance learning tool, effects, opinion

\section{INTRODUCTION}

Quizizz is one of the popular technologies that teachers often use to create online quizzes during distance learning (Basuki \& Hidayati, 2019). Quizizz has features that allow students to see the answer choices on their screen, see how long does it take to answer the questions, and see the final result of what they did (Suryaman et al, 2020). The features presented in Quizizz can help students appreciate quizzes, increase student motivation, student efforts in learning, and improve student academic achievement (Basuki \& Hidayati, 2019).

Several previous studies with similar discussions to this study can be utilized as benchmarks for the differences in this study, such as those performed by (Oysal \& Kuzu, 2009) and (Jamil, Tariq, \& Shami, 2012), discovered that the emergence of ICT 
(Information and Communication Technology) in current digital environment has significantly disrupted the teaching-learning system. According to the findings of a previous study conducted by (Bury, 2017) that Quizizz is the most appropriate digital teaching-learning tool in English subject, and the usage of digital learning tools such as Quizizz excites students. It ignites their interest in the topic being taught. Quizizz is a platform that allows students to collaborate and compete through interactive quiz games.

There is a previous study conducted by (Basuki \& Hidayati, 2019) which discusses about students' opinions of Kahoot! and Quizizz. The study aims to determine students' perceptions of two distance learning media, namely Kahoot! and Quizizz, the reasons students choose between the two media, and the comparison of the students' choices results. The development of the study is that more students choose Quizizz as a distance learning media because the use of Quizizz increases students' enthusiasm in learning.

There is another similar study conducted by (Zuhriyah \& Pratolo, 2020). The study was about "Exploring Students' Views on the Use of Quizizz as an Assessment Tool in English as a Foreign Language." The purpose of the study was to discover how to utilize Quizizz from the students' point of view, according to the title stated. The study found that Quizizz as an assessment tool received positive responses from students. Quizizz is an attractive tool and can increase students' motivation to learn, improve reading skills, and increase students' courage.

These studies have a similar goal, namely to find out students' perceptions of the Quizizz application. In addition, a study conducted by (Priyanti et al., 2019) examines the effect of using Quizizz on students' reading fluency. The study used an experimental method using post-test and eleventh-grade students as the research sample. The results of this study indicate a significant effect of using Quizizz on the level of students' reading fluency.

The above studies have explained the perceptions and effects of using Quizizz as a distance learning tool. Therefore, this study was conducted to expand and strengthen the findings of previous studies. This study will be conducted in a different place and 
sample. In the earlier studies, perception and effect have their respective articles. In this study, the effects and opinions, both will be involved in the conclusions obtained.

Many students are learning English using Quizizz with great enthusiasm. The researchers are eager to know if his friends are also very enthusiastic when learning to use Quizizz. The researchers also wanted to know how students perceive Quizizz, whether they think Quizizz is a game or a hassle for them, what effect it has on their use of Quizizz, and the researchers also want to know how effective Quizizz is as a distance learning tool.

Teachers are forced to be more innovative in their instruction of their students as a result of distance learning. During the pandemic, many teachers are utilizing the Quizizz application in distance learning along with the advancement of Technology, Information, and Communication (ICT) in the sphere of education. Researchers are attempting to ascertain students' impressions of Quizizz as a pedagogical instrument in the implementation of online quizzes for learning. This study is expected to encourage other researchers and teachers to use Quizizz as distance learning tool in English subject.

In connection with several research reports on Quizizz, this study aims to address the following questions:

1. What is the effect of using Quizizz as distance learning tool?

2. What are students' opinions of using Quizizz as distance learning tool?

\section{METHOD}

This study uses a mixed method of both qualitative and quantitative methods. We use this mixed-method as it helps in collecting data better. Because according to (Brown, 2009), in mixed methods research, a researcher collects numerical information such as questionnaires and texts (from interviews) to answer research questions better.

The samples in this study were thirty-one students from the twelfth grade of MAN 13 Jakarta who had used Quizizz as an online learning material and one of the teachers 
who taught English in that class. The subject is needed to take a sample of students' perceptions and determine the effect on students using Quizizz from the teacher's side. In this regard, this study used questionnaires, interviews, and students' final grades for one year of study as instruments.

This study used a questionnaire to collect data related to student opinions on Quizizz as an online learning tool. It consisted of fifteen questions in the form of a Likert scale. Then interview with teacher and final grades of students to obtain data related to the effect of students on Quizizz from the teacher's side. For interviews with teachers, the researchers prepared approximately ten questions related to the impacts of Quizizz on students. While on students' final grades, there are thirty-one grades of students who had filled out the previous questionnaire.

The data that has been obtained is analyzed in two steps. The first step is measuring the total of responses from respondents in the Likert Scale. Responses related to student opinions are divided into five scales, Strongly Agree (SA), Agree (A), Neutral $(\mathrm{N})$, Disagree (D), and Strongly Disagree (SD). The next step is interpreting the data obtained.

To make interpretations, first, the researchers determine the score of each Likert Scale $\mathrm{SD}=1, \mathrm{D}=2, \mathrm{~N}=3, \mathrm{~A}=4, \mathrm{SA}=5$. Next, calculate the range of scores for each question in the questionnaire with the formula T $\mathrm{x}$ Pn $(\mathrm{T}$ : Number of respondents who chose, Pn: Choice of Likert scores). In addition, we also calculate the $\%$ index for the interpretation value. The final interpretation score is presented in Table 1 below:

Tabel 1. Interpretation

\begin{tabular}{cc}
\hline Score & Interpretation \\
\hline $\mathbf{0 \%}-\mathbf{1 9 , 9 9 \%}$ & Strongly Disagree \\
\hline $\mathbf{2 0 \%}-\mathbf{3 9 , 9 9 \%}$ & Disagree \\
\hline $\mathbf{4 0 \%}-\mathbf{5 9 , 9 9 \%}$ & Neutral \\
\hline $\mathbf{6 0 \%}-\mathbf{7 9 , 9 9 \%}$ & Agree \\
\hline $\mathbf{8 0 \%}-\mathbf{1 0 0 \%}$ & Strongly Agree \\
\hline
\end{tabular}




\section{RESULTS AND DISCUSSION}

This session will explain the results obtained from the two research methods used. The first sub-chapter will present the results of the interviews and the final grades of students regarding the effects of using Quizizz. Meanwhile, the second sub-chapter will explain the results of the questionnaires that have been distributed to students regarding their opinions on Quizizz as a distance learning tool.

\section{The Effects of Using Quizizz}

The data we have obtained shows that using Quizizz as a distance learning tool in English subjects positively impacts students' scores. Most of the students got high scores while using Quizizz. Diagram 1 shows more detailed data results. In diagram 1, there are students' final scores result while using Quizizz as distance learning tool.

\section{Diagram 1. Students' final scores while using Quizizz as distance learning tool}

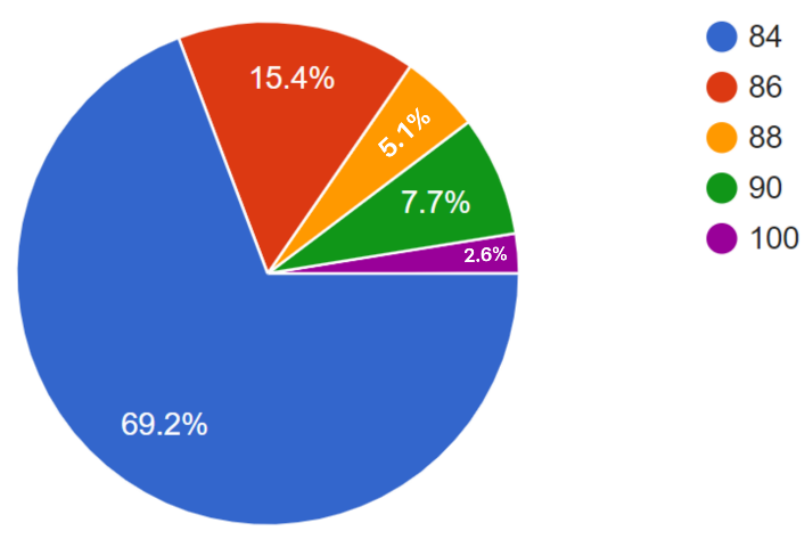

From diagram 1 above, we can see the results of students' final test scores when using Quizizz. The blue pieces of the diagram represent the percentage of students who got a score of 84 , which is 27 students with a percentage of $69.2 \%$ from $100 \%$. The red pieces of the diagram represent the percentage of students who got a score of 86 , which is 6 students with a percentage of $15.4 \%$ from $100 \%$. The orange pieces of the diagram represent the percentage of students who got a score of 88 , which is 2 students with a percentage of $5.1 \%$ out of $100 \%$. The green pieces of the diagram represent the percentage of students who got a score of 90 , which is 3 students with a percentage of $7.7 \%$ out of $100 \%$. Lastly, the purple diagram is the percentage of students who get a score of 100 , 
which is 1 student with a percentage of $2.6 \%$. In accordance with the data above, the students whose final grades were recorded were 39 people.

The data we have obtained from teacher's interviews on the question "Do you think using Quizizz makes students more competitive to get high marks? (Please give your opinion regarding this question)." We get an exciting answer. The teacher said, ".....Whether competitive or not, definitely yes. Even students will feel more competitive if the Quizizz session is done live during a zoom meeting......." This answer shows that students feel very competitive when doing the test with Quizizz.

The findings that we have obtained through teacher interviews and students' final grades have a significant difference. In accordance with the teacher's answer interview process, the effect of Quizizz on students cannot be said to be absolute. Students' improvement when learning to use Quizizz can only be seen in grammar or reading fluency and comprehension. However, Quizizz can help students read more fluently if students do it repeatedly and can also help students realize what mistakes they made in grammar. As the previous study conducted by (Priyanti et al., 2019) that reading fluency is the thing that has the most effect on students when implementing Quizizz as a distance learning tool.

In addition, Quizizz has an effect on the competitiveness of students. In accordance with a teacher's interview answer, when running a quiz, students may feel ambitious to finish it faster and more accurately than their classmates. With the leader board presented by Quizizz, students feel competitive with their friends, thus increasing their sense of competitiveness is an effect of the findings of a previous study conducted by (Pitoyo et al., 2020).

According to the previous study conducted by (Pitoyo et al., 2020) that by using Quizizz as a test tool, students become more motivated to work on it. This is in line with what one teacher said in the interview. Quizizz has an attractive appearance and features that make it easy for students to use this application as a distance learning tool.

In contrast to the final score data, we got from using Quizizz for student exams. Students get satisfactory grades in the final exam. There are no students who get a score 
below 80. Most students get a score of 84 , some other students get a score of 86 to 90 , and there is one student who gets a score of 100. This proves that Quizizz can improve student academic achievement, and the effect of Quizizz on student grades is a positive thing.

\section{Students' Opinion of Quizizz}

The data we have obtained shows that the use of Quizizz as a distance learning tool in English subjects positively impacts students. Most of the students agree while a few students disagree. Table 2 shows more detailed data results. In table 2, there are students' perceptions of Quizizz as a distance learning tool.

Tabel 2. Students' opinions of the use of Quizizz as distance learning tool

\begin{tabular}{|c|c|c|c|c|c|c|c|}
\hline NO & QUESTIONNAIRE & SD & D & $\mathbf{N}$ & $\mathbf{A}$ & SA & $\mathbf{I}$ \\
\hline 1 & $\begin{array}{l}\text { Using Quizizz for learning English is fun and } \\
\text { interesting. }\end{array}$ & - & 1 & 6 & 20 & 4 & A \\
\hline 2 & Quizizz has an interesting look & - & - & - & 22 & 9 & SA \\
\hline 3 & Quizizz has many challenging features & - & - & 4 & 7 & 20 & SA \\
\hline 4 & I enjoy doing tests using Quizizz & - & 3 & 11 & 12 & 5 & A \\
\hline 5 & $\begin{array}{l}\text { I do not want to miss a study session using } \\
\text { Quizizz }\end{array}$ & - & 1 & 11 & 17 & 2 & A \\
\hline 6 & Quizizz feels like a game & - & - & 4 & 20 & 7 & SA \\
\hline 7 & Quizizz does not stress me out on tests & 2 & 2 & 20 & 4 & 3 & A \\
\hline 8 & I cannot cheat on a test using Quizizz & - & 2 & 6 & 18 & 5 & A \\
\hline 9 & Quizizz creates a competitive atmosphere & - & - & - & 21 & 10 & SA \\
\hline 10 & $\begin{array}{l}\text { I answer every question on Quizizz as fast as I } \\
\text { can }\end{array}$ & - & - & 2 & 22 & 7 & SA \\
\hline 11 & $\begin{array}{l}\text { I feel compelled to be number one on the } \\
\text { Quizizz leaderboard }\end{array}$ & - & 1 & 3 & 19 & 8 & SA \\
\hline 12 & Quizizz is better than written test & - & 5 & 6 & 16 & 4 & A \\
\hline 13 & Quizizz must be used in daily online quizzes & 1 & 6 & 13 & 10 & 1 & A \\
\hline 14 & $\begin{array}{l}\text { Quizizz helps me more easily remember what I } \\
\text { have learned }\end{array}$ & 1 & 3 & 11 & 14 & 2 & A \\
\hline 15 & $\begin{array}{l}\text { Quizizz helped me to instantly find out and } \\
\text { correct my answer mistakes }\end{array}$ & - & 1 & 2 & 18 & 10 & SA \\
\hline \multicolumn{2}{|c|}{ SCORE } & 4 & 25 & 99 & 240 & 97 & A \\
\hline \multicolumn{2}{|c|}{ Score x Option Value } & 4 & 50 & 297 & 960 & 485 & \\
\hline \multicolumn{2}{|c|}{ TOTAL SCORE } & & & & & 1796 & \\
\hline
\end{tabular}

From table 1, it can be seen that from 15 statements, the average student chose to strongly agree on 7 statements. The seven statements are: Quizizz has an interesting look, 
Quizizz has many challenging features, Quizizz feels like a game, Quizizz creates a competitive atmosphere, I answer every question on Quizizz as fast as I can, I feel compelled to be number one on the Quizizz leaderboard, and Quizizz helped me to instantly find out and correct my answer mistakes.

In addition, the average students chose to agree with the remaining eight statements. The eight statements are: using Quizizz for learning English is fun and interesting, I enjoy doing tests using Quizizz, I do not want to miss a study session using Quizizz, Quizizz does not stress me out on tests, I cannot cheat on a test using Quizizz, Quizizz is better than written test, and Quizizz must be used in daily online quizzes.

The questionnaire results prove that students from MAN 13 Jakarta have positive opinions of the use of Quizizz application as a distance learning tool. The questionnaire result had a total score of 1796, which was acknowledged with agree. Despite the positive student opinions of the use of Quizizz, the interpretation results are not in agreement with the previous study conducted by (Amalia, 2020) that students showed positive perceptions of Quizizz's use as a digital assessment tool for English language teaching, particularly on a constructive approach.

From the table given, the questionnaire item Quizizz has many challenging features received the most encouraging response from students because it got the most results in the interpretation of strongly agree. From the table that discusses the appearance and performance of the Quizizz application, the questionnaire item that can be interpreted agree is Quizizz is better than a written test. Meanwhile, it can be interpreted that the students strongly agreed with the other four statements. The statements were Quizizz has an interesting look, Quizizz feels like a game, and Quizizz creates a competitive atmosphere. This is aligned with a prior study by (Basuki, 2019), which found that the majority of students feel that Quizizz is engaging, fascinating, inspiring, and fun.

Based the score of interpretation, most students chose to agree with the statements according to table 1 in the statement category when using the Quizizz application. The accepted statements are: I enjoy doing tests using Quizizz, I do not want to miss a study session using Quizizz, and I cannot cheat on a test using Quizizz. Meanwhile, students strongly agree with two other statements: I answer every question on Quizizz as fast as I 
can, and I feel compelled to be number one on the Quizizz leaderboard. This is in line with a previous study conducted by (Suryaman, Akbar, and Salsabila, 2020) which showed that using the Quizizz application increased students' interest and competitiveness, but few students still thought of cheating. However, pro and contra in such a new platform of learning should be considered based on the significance (Wahyunengsih, 2018).

The following statement is Quizizz helped me to instantly find out and correct my answer mistakes, with an interpretation score of strongly agree indicating that students can find the correct answer quickly through Quizizz. While the following three statements are in the same category, Quizizz does not stress me out on tests, Quizizz must be used in daily online quizzes, and Quizizz helped me to instantly find out and correct my answer mistakes showing the score interpretation agree. Of the four statements above, Quizizz does not stress me out on tests, which is not in line with previous research conducted by (Amalia, 2020), in the study, which showed that students felt tension when taking tests with Quizizz.

\section{CONCLUSION}

From the findings and discussion above, we can conclude that Quizizz received positive responses from teachers and students as a distance learning tool. Students agree that Quizizz has an attractive appearance and challenging features. And this feature creates a sense of competitiveness among students. The teacher's statement reinforces that every time they use Quizizz, the students look more enthusiastic and ambitious to be in first place on the leaderboard. Besides that, many students also agree that Quizizz doesn't stress them out while doing the test.

Based on the teacher's interview answers, we can see that the overall effect of Quizizz on students is not very significant. But in some aspects, such as fluency and reading comprehension, Quizizz has a very positive impact, so that it can improve the quality of students in these aspects.

For further research, the researchers suggest conducting a more in-depth analysis regarding the effect of Quizizz on student learning because there is still a lack of research 
that discusses this matter and the need for more in-depth knowledge of the influence of Quizizz on students.

\section{REFERENCES}

Amalia, D. F. (2020). Quizizz Website As An Online Assessment For English Teaching And Learning: Students' Perspectives. Journal of English Language Teaching (Jo-ELT), 1-8.

Basuki, Y., Hidayati, Y. N. (2019). Kahoot! or Quizizz: the Students' Perspectives. Proceedings of the 3rd English Language and Literature International Conference (ELLiC).

Bury, B. (2017). Testing Goes Mobile - Web 2.0 Formative Assessment Tools. International Conference ICT for Language Learning.

Creswell, J. W. (2012). Educational Research. Pearson Education.

Darma, S. (2016). Students' Perception of the Use of Kahoot! as an Ice Breaker in Interpretation Class. Yogyakarta: Sanata Dharma University.

Gbollie, C., \& Keamu, H. (2017). Student Academic Performance: The Role of Motivation, Strategies, and Perceived Factors Hindering Liberian Junior and Senior High School Students Learning. Education Research International, 1-11. doi: $10.1155 / 2017 / 1789084$

Jamil, M., Tariq, R.H., \& Shami, P.A. (2012). Computer-Based vs. Paper-Based Examinations: Perceptions of University Teachers, TOJET: The Turkish Online Journal of Educational Technology, 11(4), 371-381.

James D. Brown, T. R. (2002). Doing second language research. Oxford: Oxford University Press.

Licorish, S., Owen, H., Daniel, B., \& George, J. (2018). Students' perception of Kahoot!'s influence on teaching and learning. Research and Practice in Technology Enhanced Learning, 13(1). doi: 10.1186/s41039-018-0078-8

Muhammad. (2020). Promoting Students ${ }^{\text {ee }}$ Autonomy through Online Learning Media in EFL Class. International Journal of Higher Education, 320-331.

Pitoyo, M. D., Sumardi, \& Asib, A. (2020). Gamification-Based Assessment: The Washback Effect Of Quizizz On Students' Learning In Higher Education. International Journal Language of Education, 1-10.

Priyanti, N. W. I., Santosa, M. H., \& Dewi, K. S. (2019). Effect Of Quizizz Towards The Eleventh-Grade English Students' Reading Comprehension In Mobile Learning Context. Language and Education Journal Undiksha (LOJU), 71-80. 
Suryaman, M., Akbar, F., \& Salsabila, S. (2020). English Education Students as PreService English Teachers' Perception on Quizizz: Considering Mall Utilization as a Pedagogical Tool. Indonesia Technology Enhanced Language Learning (iTELL), 139-142.

Uysal, O., \& Kuzu, A. (2009). A Thesis Proposal: Quality Standards of Online Higher Education in Turkey. EMUNI Conference on Higher Education an Research .

Wahyunengsih, W. (2018). Teachers' Perspective on the Challenges of Teaching English for Specific Purposes in Indonesia. Journal of English for Academic and Specific Purposes, 1(1), 22. https://doi.org/10.18860/jeasp.v1i1.5243

Zuhriyah, S., \& Pratolo, B. W. (2020). Exploring Students' Views in the Use of Quizizz as an Assessment Tool in English as a Foreign Language (EFL) Class. Universal Journal of Educational Research, 5312-5317. 